\title{
UMKE Çalışanlarının Afet Durumunda Etik Yaklaşımlarının İncelenmesi: Güney Marmara Örneği
}

\author{
The Research on The Ethical Attitudes of UMKE Staff During Disaster: Example of South Marmara
}

\author{
Emrah GÖKKAYA ${ }^{1}$, Ayten DİNÇ²
}

\begin{abstract}
ÖZ
$\mathrm{Bu}$ araştırmanın amacı, UMKE çalışanlarının afet durumundaki etik yaklaşımlarının incelenmesidir. Araştırma tanımlayıcı nitelikte olup, Ağustos 2016Ağustos 2017 tarihleri arasında gerçekleştirilmiş̧ir. Araştırmanın evrenini Güney Marmara Bölgesinde çalışan 264 UMKE personeli, örneklemini çalışmayı kabul eden 201 UMKE çalışanı oluşturmuştur. Veriler yüz yüze görüşme yöntemiyle, anket formu ile toplanmıştır. Verilerin değerlendirilmesinde, frekans, yüzde, ki-kare testi kullanılmıştır.

Araştırmada UMKE çalışanlarının \%44'ü etik ikilem ile sürekli karşılaştıklarını, \%64'ü etik ikilemden dolayı verimliliklerinin etkilendiğini belirtmiştir. UMKE çalışanlarını afet sırasında etik ikilemde bırakan uygulamalar; afetzedeyi transport durumu $(\% 33,8)$, afetzede yakınları $(\% 26,9)$, KPR (kardiyopulmoner resüsitasyon) uygulamasına karar verme $(\% 22,9)$, hastane koordinasyon eksikliğidir $(\% 16,4)$. KPR'a karar verirken en fazla aileye açıklamada zorlanmaktadırlar. UMKE çalışanlarının \%30,3'ü her zaman, \%62'si bazen karşılaştıkları etik problemlerin çözümü için yardıma ihtiyaç duymakta, $\% 62,3$ 'ü meslektaşlarından bu konuda yardım almaktadır. UMKE çalışanlarının afet hizmeti sunumunda; \%20,4'ünün zarar vermeme, \%23,9'unun yararlı olma, \%17,9'unun adalet, \%19,9'unun özerklik, \%17,9'unun mahremiyet yükümlülüğünü dikkate almadıkları saptanmıştır. Katılımcıların \%66,2'sinin daha fazla etik eğitim alma gereksinimi duydukları belirtilmiştir.
\end{abstract}

UMKE çalışanlarına afet durumlarında etik yaklaşım ve etik ikilemlerin çözümü ile daha fazla hizmet içi eğitimler verilmelidir

Anahtar Kelimeler: Afet, Etik Yaklaşım, UMKE Çalışanı

\begin{abstract}
The aim of this study is to investigate the ethical approaches of UMKE (Turkish National Medical Rescue Team) personnel in disaster situations. The August 2016-2017 was conducted with a descriptive nature of the research. The population of the study consisted of 264 UMKE personnel working in the South Marmara Region and 201 UMKE employees who accepted the study. Data were collected by faceto-face interview method and questionnaire form. Frequency, percentage, chi-square test are used to evaluate the data.
\end{abstract}

In the survey, $44 \%$ of UMKE personnel stated that they experience continuously with ethical dilemma and $64 \%$ stated that their productivity has affected because of the ethical dilemma. The training that leaves UMKE personnel in ethical dilemma during disaster education; transport status of the victim (33.8\%), relatives of the victim (26.9\%), decision to apply CPR (cardiopulmonary resuscitation) (22.9\%), lack of hospital coordination (16.4\%). When deciding on CPR, they have the most difficulty explaining to the family. $30.3 \%$ of UMKE personnel always and $62 \%$ of them sometimes need help to solve the ethical issues they face, $62.3 \%$ get help from their colleagues. In the disaster service provision of UMKE personnel; they didn't take into account $20.4 \%$ not to harm, $23.9 \%$ of them are useful, $17.9 \%$ of justice, $19.9 \%$ of autonomy, $17.9 \%$ of privacy obligation. It was stated that $66.2 \%$ of the respondents needed to receive more ethical training.

UMKE personnel should be given more in-service training with ethical approach and solution of ethical dilemmas in disaster situations.

Keywords: Disaster, Ethical Attitudes, UMKE Personnel

\footnotetext{
*Bu çalışma yüksek lisans tez çalışmasından üretilmiştir.

${ }^{1}$ Öğretim Görevlisi, Afet Eğitimi ve Yönetimi, Kayseri Üniversitesi Bünyan Meslek Yüksekokulu Sivil Savunma ve İtfaiyecilik Programı, egokkaya@kayseri.edu.tr ORCID: 0000-0002-1373-3188

${ }^{2}$ Doç. Dr. Ayten Dinç, Çanakkale Onsekiz Mart Üniversitesi Sağlık Bilimleri Fakültesi Ebelik Bölümü, aytendinc@comu.edu.tr ORCID: 0000-0002-8903-675X

\begin{tabular}{|c|c|c|c|}
\hline İletişim / Corresponding Author: & Emrah GÖKKAYA & Geliş Tarihi / Received: & 15.05 .2019 \\
\hline e-posta/e-mail: & egokkaya@kayseri.edu.tr & Kabul Tarihi/Accepted: & 09.01 .2020 \\
\hline
\end{tabular}
}




\section{GİRIŞ}

Afet; sosyal, fiziksel, ekonomik ve birçok yönden çevresel kayıplar oluşturan, sıradan hayatı ve insan etkinliklerini dondurarak ya da sekteye uğratarak toplumları sarsan ve sarsılan toplumun kendi imkânlarından faydalanarak baş edemeyeceği teknoloji, insan ve doğa sebepli olayların neticeleridir. ${ }^{1}$ Hayat akışında olumsuz bir iz bırakan afetlerin, gitgide küreselleşen dünyamızdaki izlerini hafifletmek de oldukça güç olmaktadır. Ayrıca, afet durumunda zorlaşan koşulları bir de etik değerler açısından düşünmemiz gerektiğinden afet yönetim sistemi işleyişi oldukça önem arz etmektedir.

Etik kavram1, bir grubun üyelerinden meslek ilkelerine uygunluk içerisinde beklenen davranış biçimleri ve ölçütleriyle bağlantılı olarak kullanılır. Etik kavramı aynı zamanda insan davranışlarının ahlaki boyutunu anlamada ve insanın iyi olmasıyla ilgili sorulara yanıt bulmada bize yardımcı olur. Etik, her şeyden önce istenilecek bir hayatın anlaşılması ve araştırılmasıdır. Daha kapsamlı olarak tüm faaliyet ve gayelerin yerine konulması; hangisinin yapılacağı veya yapılamayacağının; hangisinin isteneceği veya istenemeyeceğinin; hangisinin sahip olunacağı veya olunamayacağının bilinmesidir. $^{2}$

Afetlerde etik yaklaşım; afet öncesi, afet anı ve afet sonrasında farkl1lıklar gösterir. Afet öncesi dönemde, afet acil durum planlamaları, risk analizleri yapılarak stratejiler geliştirilir. Afet sırası dönem müdahale çalışmalarının yapılması, kaynakların etkin kullanılması, acil sağlık, beslenme, barınma gibi temel ihtiyaçların karşılanması ve olağan dışı durumla başa çıkabilmeyi gerektirir. Afet sonrası dönemde ise iyileştirme ve yeniden yapılandırma çalışmaları ile afetin olumsuz etkilerinin giderilmeye çalışıldığı dönemdir. ${ }^{3}$

Afet risklerini en aza indirmek için ilk olarak bir stratejik planın oluşturulması gerekir. Afet planlarından halkın haberi olmalı, insanların refahını olumlu bir şekilde korumalı, zarar vermemek için etik ilkelere uygun olmalıdır. ${ }^{4}$
Normal hayatta toplum olarak uymakta pek fazla sıkıntı ile karşılaşmadığımız etik ilkelerde, afet anında oluşan kaos ve krizle uyulmasında zorluk çıkabilir. Bu durumlarda etik açıdan değerlendirilmesi gerekli olan aktörler; bütünleşik bir açıdan bakıldığında yerel yönetim kurum ve kuruluşları ile merkezi yönetim, ayrıca sivil gruplar ve kişilerdir.

Afetzedelere yardım için dünyanın çeşitli ülkelerinden gelen afet gönüllüleri, farklı kültür, inanç, ekonomik şartlara ve politik anlayışa sahiptirler. Afetlerde görev alacak gönüllü personel ve kuruluşların, buralarda yapılacak çalışmaların temel felsefesine uygun mesleki ve etik ilkeler konusunda yetiştirilmesi gerekmektedir. ${ }^{5}$

Ulusal Medikal Kurtarma Ekipleri (UMKE), her türlü afet ve olağan dişı durumlarda yeterli ve nitelikli sağlik hizmeti sunmak, afetle ilgili kurum, kuruluş ve kişilerle iletişimi sağlamak amaciyla gönüllülük esasına dayalı olarak sağlıkçılar arasından seçilmiş, gerekli eğitimi almış personellerdir. UMKE çalışanları, afetzedenin durumundaki değişimleri ilk önce tespit eden, acil durumları timler arasında bir an önce karara bağlaması gereken sağlık çalışanı olarak, beklenmeyen durumda meydana gelen karmaşık problemlerle sıkça karşılaşmaktadır. $\mathrm{Bu}$ problemlerin büyük bölümünü etik problemler meydana getirir. UMKE çalışanlarının kazazedeye yaklaşımında etik karar verme sürecini etkileyen durumlar genellikle; triaj, medikal karar alma, aydınlatılmış onam alma, medikal stokların eşit dağıtılması sayılabilir. ${ }^{3,6}$

Afetlere etik yaklaşımın, afetzedeler ve müdahale ekiplerinde afet sonrası kalıcı bir iz kalmaması adına hassasiyet içeren bir konu olduğu görülmektedir. Ülkemizde afetlerde etik yaklaşım konusu ile ilgili yapılan çalışmalar oldukça azdır. Bu çalışma Güney Marmara Bölgesindeki UMKE çalışanlarının afet durumunda etik yaklaşımlarının incelenmesi amacıyla planlanmıştır. 


\section{MATERYAL VE METOT}

\section{Araştırmanın Şekli}

Araştırma tanımlayıcı nitelikte olup, 15 Ağustos 2016-15 Ağustos 2017 tarihleri arasında yapılmıştır.

\section{Araştırmanın Evren ve Örneklemi}

Araştırmanın evrenini, Güney Marmara Bölgesi olarak Çanakkale, Bursa, Balıkesir, Yalova illerinde çalışan UMKE personelleri oluşturmaktadır.

Günümüzde 81 il merkezinde UMKE yapılanması kurulmuş olup, timler oluşturulmuş ve 2016 y1lı itibari ile 7500 gönüllü UMKE çalışanı mevcuttur. ${ }^{9}$ Acil Sağlık Hizmetleri Genel Müdürlüğü'nden elde edilen bilgilere göre, Çanakkale'de 49, Bursa'da 110, Balıkesir'de 80, Yalova'da 25 ve toplamda 264 UMKE personeli bulunmaktadır. Güney Marmara Bölgesindeki 264 UMKE gönüllüsünden 214'üne ulaşılmış ve araştırmayı kabul eden 201 kişi örneklem grubunu oluşturmuştur.

Araştırmaya alma ölçütleri; Sağlık Bakanlığına bağlı çalışanlar arasından UMKE gönüllüsü olması ve çalışmayı kabul etmesi, araştırmaya almama ölçütleri; UMKE gönüllüsü olmaması ve çalışmayı kabul etmemesidir.

Araştırmanın bağımlı değişkeni; UMKE'de çalışan sağlık personeli olması, bağımsız değişkenleri ise; yaş, cinsiyet, öğrenim durumu, çalıştığı kurum, hizmet süresi ve statüdür.

\section{Verilerin Toplanması}

Anketlerin büyük çoğunluğu araştırmacı tarafından 2016 yılı Güney Marmara UMKE son bölge kampı olan Balıkesir bölge kampına gidilerek yüz yüze görüşme tekniği kullanılarak uygulanmıştır. Diğer anketler ise, UMKE personellerinin çalıştıkları Acil Sağlık Hizmetleri İstasyonları ziyaret edilerek uygulanmıştır.

Araştırmac1 tarafindan literatürden yararlanılarak hazırlanan anket formu, sosyo- demografik bilgiler bölümü, etik yaklaşım bölümü ve afet sırası etik yaklaşım bölümü olmak üzere 3 bölümden oluşmuştur. ${ }^{7-8}$

Anketin ilk bölümü sosyo-demografik özellikler (cinsiyet, yaş, öğrenim durumu, kurum bilgisi, meslek ve hizmet y1li) bilgilerini içeren 6 sorudan oluşmuştur. Anketin ikinci bölümünde yer alan etik yaklaşım kısmı UMKE çalışanlarının etik problemlere genel yaklaşımını, etik ile ilgili eğitim alma durumları, etik komite ile ilgili bilgilerini sorgulayan 11 adet soruyu kapsamaktadır. Anketin üçüncü bölümünde yer alan afet sırası etik yaklaşım kısmı ise, UMKE çalışanlarının afet durumlarındaki karşılaştıkları etik ikilemleri ve etik yaklaşımlarını içeren 11 adet soruyu kapsamaktadir.

Anket formunu uygulamadan önce araştırma kapsamına alınan UMKE çalışanlarına bu çalışmanın ne amaçla yapıldığı, neden bu çalışmaya seçildikleri anlatılmış, katılmaya gönüllü UMKE çalışanlarından onam alınarak çalışmaya dahil edilmiştir. Anketin doldurulması yaklaşık 1015 dakika sürmüştür.

\section{Araştırmanın Etik Yönü}

Araştırmanın yapılabilmesi için Acil Sağlık Hizmetleri Genel Müdürlüğü'nden resmi izin (19.10.2016 tarih ve 39942531724.01.01 sayılı yazı) ve Çanakkale Onsekiz Mart Üniversitesi Sosyal Bilimler Enstitüsü Etik Kurulu'ndan yazılı izin alınmıştır (Karar No: 2016/23).

\section{Verilerin Analizi}

Çalışmadan elde edilen verilerin değerlendirilmesinde, SPSS 22.0 (Statistical Package for The Social Science) programından yararlanılmıştır. Verilerin değerlendirilmesinde, frekans, yüzde oranları ve araştırma hipotezlerinin testinde iki kategorik değişkenin bağımsızlığı karşılaştırıldığından Ki-Kare Bağımsızlık analizi uygulanmıştır. 


\section{BULGULAR VE TARTISSMA}

Çalışmada UMKE çalışanlarının \%52,2'si erkek, $\% 47,8$ 'i ise kadındır. Katılımcıların büyük çoğunluğu 25-35 yaş aralığında olup, yaş ortalamaları 28,22'dir. Çalışanların 75,6's1 önlisans/lisans mezunu, çoğunluğu (\%71,6'sı) 112 Acil Sağlık istasyonlarında görevlidir. Meslek ve hizmet süreleri incelendiğinde, \%75,6's1 acil tıp teknisyeni (ATT)/paramedik statüsünde ve \%37,3’ü 3-6 yıldır hizmet vermektedir (Tablo 1).

Tablo 1. UMKE Çalışanlarının Sosyo-Demografik Özellikleri $(\mathbf{n}=201)$

\begin{tabular}{llll}
\hline Değişken & & $\mathbf{n}$ & $\mathbf{\%}$ \\
\hline Cinsiyet & Erkek & 105 & 52,2 \\
& Kadın & 96 & 47,8 \\
\hline Yaş & $18-24$ & 76 & 37,8 \\
& $25-34$ & 88 & 43,8 \\
& $35-44$ & 29 & 14,4 \\
& 45 ve $\geq$ & 8 & 4,0 \\
\hline Öğrenim & Ortaöğretim & 42 & 20,9 \\
Durumu & Ön lisans & 88 & 43,8 \\
& Lisans & 64 & 31,8 \\
& Lisansüstü & 7 & 3,5 \\
\hline Kurum & Devlet Hast. & 41 & 20,4 \\
& 112 & 144 & 71,6 \\
& Diğer & 16 & 8,0 \\
\hline Meslek & Hekim & 2 & 1,0 \\
& Hemşire & 39 & 19,4 \\
& ATT & 76 & 37,8 \\
& Paramedik & 76 & 37,8 \\
& Diğer & 8 & 4,0 \\
\hline Hizmet & 0-3 yıl arası & 50 & 24,9 \\
& 3-6 yıl arası & 75 & 37,3 \\
& 6-10 yıl & 26 & 12,9 \\
& 10 ve $\geq$ & 50 & 24,9 \\
\hline
\end{tabular}

Tablo 2'de görüldüğü gibi UMKE çalışanlarının \%44'ü etik ikilem ile sürekli karşılaştıklarını, \%64'ü etik ikilemden dolayı verimliliklerinin etkilendiğini belirtmiştir. Çalışanları afet sırasında etik ikilemde birakan uygulama incelendiğinde ise; \%33,8'i afetzedeyi transport durumunda, \%26,9 afetzede yakınlarının yaklaşımları sonucu, \%22,9'u KPR (kardiyopulmoner resüsitasyon) uygulamasina karar verme, $\% 16,4$ 'ü hastane koordinasyon eksikliğinden kaynaklanmaktadır. KPR'a karar verirken yaşadıkları etik ikilemler incelendiğinde; aileye açıklamada zorlanma $(\% 28,4)$, zamanlama $(\% 22,4)$, duygusal etkilenme $(\% 18,9)$, aydınlatılmış onam alma $(\% 15,9)$, KPR'a karar vermedir $(\% 14,4)$.

Tablo 2. UMKE Çalışanlarının Afet Durumunda Etik İkilemlerle Karşılaşma Durumları

\begin{tabular}{lcc}
\hline Değişken & n & \% \\
\hline Etik İkilem ile Karşılaşma Durumu & \\
Sik Karşılaşıyoruz & 90 & 44,8 \\
Bazen Karşılaşıyoruz & 61 & 30,3 \\
Kararsızım & 50 & 25,9 \\
\hline \multicolumn{2}{l}{ Çalışanların Etik Çelişkilerin Afet Sırası } \\
Verimliliklerini Etkileme Durumu \\
Evet & 129 & 64,2 \\
Hayır & 24 & 11,9 \\
Kararsızım & 48 & 23,9 \\
\hline Çalışanları Afet Sırasında Etik İkilemde \\
Bırakan Uygulama & \multicolumn{2}{|c}{} \\
KPR Uygulaması & 46 & 22,9 \\
Transport Durumu & 68 & 33,8 \\
Afetzede Yakınları & 54 & 26,9 \\
Hastane Koordinesi & 33 & 16,4 \\
\hline KPR’a Karar Verirken Yaşanan Kararsızlık \\
Aydınlatılmış Onam & 32 & 15,9 \\
Zamanlama & 45 & 22,4 \\
Aileye Açıklama & 57 & 28,4 \\
Karar Verme & 29 & 14,4 \\
Duygusal Açıdan & 38 & 18,9 \\
\hline
\end{tabular}

UMKE çalışanlarının \%30,3'ü etik problemin çözümü için her zaman yardıma ihtiyaç duyduklarını, \%24,9'u her zaman yardım aldığını, \%62,2'si meslektaşlarından yardım aldıklarını bildirmişlerdir (Tablo 3). Çalışmada UMKE çalışanlarının etik problemin çözümü için ihtiyaç duyma durumu bazı sosyo-demografik verilerle karşılaştırılmış; cinsiyet, yaş, öğrenim durumu, kurum, meslek açısından aralarında istatistiksel olarak anlamlı bir ilişki bulunmamıştır ( $p>0,05)$. Ancak, hizmet süresi 0-3 yıl ve 3-6 yıl olanlarda etik sorun çözümü için her zaman ihtiyaç duyanların oranının daha fazla olduğu saptanmıştır (sırasıyla \%34, $\% 38 ; \mathrm{p}=0,014)$. 
Tablo 3. UMKE Çalışanlarının Etik Problemin Çözümüne İlişkin Yaklaşımlar

\begin{tabular}{lcc}
\hline Değişken & n & \% \\
\hline Etik Problemin Çözümü için Yardıma İhtiyaç Duyma \\
Her Zaman & 61 & 30,3 \\
Bazen & 125 & 62,2 \\
Hiçbir Zaman & 15 & 7,5 \\
\hline Etik Problemin Çözümü İçin Yardım & Alma \\
Her Zaman & 50 & 24,9 \\
Bazen & 119 & 59,2 \\
Hiçbir Zaman & 32 & 15,9 \\
& & \\
Etik Problemin Çözümü için Kimden & Yardım \\
Alındığı & & \\
Meslektaşlarımdan & 126 & 62,7 \\
Aile üyeleri/güven & \multicolumn{2}{|c}{} \\
duyduğu kişi & 41 & 20,4 \\
Hukukçulardan & 7 & 3,5 \\
Etik komitelerden & 12 & 6,0 \\
Diğer & 15 & 7,4 \\
\hline
\end{tabular}

UMKE çalışanlarının afet hizmeti sunumunda yer alan etik yükümlülüklerden hangisini dikkate almadıkları incelendiğinde; $\% 20,4$ 'ü zarar vermeme, \%23,9'u yararlı olma, \%17,9'u adalet, \%19,9'u özerklik, $\% 17,9$ 'u ise mahremiyet yükümlülüğünü dikkate almadığını belirtmiştir (Tablo 4).

Tablo 4. Afet Hizmeti Sunumunda Yer Alan Etik Yükümlülüklerden Hangilerinin Dikkate Alınmadığı

\begin{tabular}{lcc}
\hline $\begin{array}{l}\text { Etik } \\
\text { Yükümlülükler }\end{array}$ & $\mathbf{n}$ & $\mathbf{\%}$ \\
\hline Zarar vermeme & 41 & 20,4 \\
Yararlı olma & 48 & 23,9 \\
Adalet & 36 & 17,9 \\
Özerklik & 40 & 19,9 \\
Mahremiyet & 36 & 17,9 \\
\hline Toplam & $\mathbf{2 0 1}$ & $\mathbf{1 0 0 , 0}$ \\
\hline
\end{tabular}

UMKE çalışanlarının \%80,2 si $(n=162)$ etik ile ilgili eğitim/kurs almıştır. Ayrıca, çalışanların \%66,2'si daha fazla etik eğitim alma ihtiyaçları olduklarını bildirmişlerdir (Tablo 5). Ülkemizde UMKE çalışanlarının büyük çoğunluğunun 112 'de çalışan sağlik personelinden oluştuğu görülmektedir. ${ }^{10} \mathrm{Bu}$ çalışmada da UMKE çalışanlarının \%75,6'sı acil tıp teknisyeni/paramedik statüsündedir. Ünal ve ark. (2017) Marmara Bölgesi'nde UMKE çalışanlarına yaptıkları çalışmada bu çalışmadan farklı olarak UMKE çalışanlarının \%28'i ATT/Paramediklerden oluşmaktadır. ${ }^{11}$
Durumu ve Eğitim İhtiyacı

\begin{tabular}{lcc}
\hline Değişken & $\mathbf{n}$ & $\boldsymbol{\%}$ \\
\hline Etik Ĕgitim/Kurs Alma Durumu & \\
Evet & 162 & 80,2 \\
Hayır & 39 & 19,8 \\
Daha Fazla Etik Eğitim Alma İhtiyacı & \\
Evet & 133 & 66,2 \\
Hayır & 26 & 12,9 \\
Kararsızım & 42 & 20,9 \\
Toplam & $\mathbf{2 0 1}$ & $\mathbf{1 0 0 , 0}$ \\
\hline
\end{tabular}

Etik ikilem, herhangi bir olay anında karar alınması gereken bir durumda farklı iki yaklaşım arasındaki kararsızlıktan doğar. Sağlık çalışanları da özellikle acil durumlarda hastalar için en iyisi olacak olan duruma karar verirken, kendi yargıları ve değerleri arasında kalarak etik ikilemde kalabilirler. Literatürde de sağlık çalıșanlarının etik ikilemlerle sık sık karşı karşıya kaldığ 1 bildirilmektedir. ${ }^{12-15} \mathrm{Bu}$ çalışmada UMKE çalışanlarının \%44,8'i afet durumunda sürekli etik ikilem ile karşılaştıklarını belirtmiştir (Tablo 2).

Araștırmada UMKE çalışanlarının \%64'ü etik ikilemlerin afet durumlarında verimliliklerini etkilediğini bildirmiştir (Tablo 2). Literatürde bizim çalışmamızı destekler nitelikte çalışmalar mevcuttur. Gül ve ark. (2016) yaptıkları çalışmasında sağlık çalıșanlarında etik çelișkilerin verimliliklerini etkilediklerini saptamışlardır. ${ }^{16}$ Filizöz ve ark. (2015) sağlı çalışanlarının etik duyarlılıklarını belirlemek amacıyla yaptıkları çalışmalarında sağlık çalışanlarının etik olarak doğru eylemin ne olduğunu bulmakta ve karar vermekte zorlandiklarını, ayrıca hastalara nasıl yaklaşması gerektikleri konusunda sıklıkla çelişkide kaldıklarını saptamışlardır. Bu durumu etik eğitimlerinin yetersiz olduğuna bağlı olduğunu belirtmişlerdir. ${ }^{17}$ Elçigil ve ark. (2011)'nın bir Üniversite Hastanesi'ndeki hemșirelerin karşılaştıkları etik ikilemleri inceledikleri çalışmalarında, etik ikilemde kalan hemşirelerin bu problemi çözmek için fazla zaman harcadıklarını ve bu durumun iş verimini olumsuz etkilediğini belirtmişler ve hizmet içi eğitimlerin önemini vurgulamışlardır. ${ }^{18}$ 
Araştırmada UMKE çalışanlarının afet sırasında etik ikilemde kaldıkları uygulamalar sirasiyla; transport esnasinda, afetzede yakınlarının çeşitli müdahaleleri konusunda, KPR uygulamas1 ve hastane koordinasyon yetersizliği ile ilgilidir (Tablo 2). Çalışmada UMKE çalışanlarının \%33'ünün hastaların önceliklerine göre yapılması gereken transport yetersizliğinden kaynaklı etik ikilemde kaldıkları görülmüştür. Yıldız ve Durukan (2004) yaptıkları çalışmalarında ambulanslarda sağlık çalışanlarının hasta transportu sirasinda sevk kurallarına uymadıkları ve hasta transportunda yetersiz kaldığını belirtmişlerdir. ${ }^{19}$ Çalışmamızda afet sırasında bir diğer etik ikilem olarak çalışanların \%26'sının hasta yakınları ile yaşadıkları sorunlar sebepli etik ikilemde kaldığg görülmüştür. Gezer (2010) yaptığı çalışmasında, sağlık çalışanlarının en sık karşılaştı̆̆ 1 etik ikilemlerin birinin hasta yakınları ile yaşadıkları sorunlar olduğunu saptamıştır. $^{20}$

KPR uygulama ya da uygulamama ikilemi zor ve ağır sorumlulukları olan bir durumdur. Çünkü sağlık çalışanları için olayın hukuki boyutunun yanı sira etik ve manevi değerler bakımından oldukça yıpratıcı olabilmektedir. ${ }^{21}$ Araştırmada UMKE çalışanlarının \%22,9'u afet sırasında KPR'a karar verirken kararsızlık yaşadığını belirtmiştir. KPR için yaşanan kararsızlık durumlarına bakıldığında ise, en sık aileye açıklama konusunda etik ikilemde kalınmıştır. Diğer ikilem durumları sırasıyla, zamanlama, duygusal anlamda, aileden KPR yapmak için onam alma, KPR'a karar verip uygulamaya geçme aşamasıdır. Bu konu ile ilgili literatür çalışmalarına baktığımızda; Gönenç (2015) yaptığ 1 çalışmasında KPR konusunda hasta yakınından aydınlatılmış onam almanın sağlık çalışanlarına hukuki ve etik sorumluluklar yüklediğini ve çözülmesi zor sorunlara yol açtığını belirtmiştir. Ayrıca KPR uygulamasının hastanın yaşama dönmesi ile hayatının sonlanması arasında uygulanması gereken bir seçim olduğundan karar verilmesi zor bir durum olduğunu belirtmiştir. ${ }^{22}$ Çiçekci ve Atıcı (2013) ise yaptıkları çalışmasında KPR konusunda zamanlamanın önemli olduğunu ilk 20 dakika içerisinde yapılan müdahaleler ile hastaların yaşama dönme ihtimallerinin daha yüksek olduğunu saptamışlar ve bundan dolayı resüsitasyonun zamanlama açısından önemini vurgulamışlardır. ${ }^{23}$

Çalışmada afet sırasında UMKE çalışanlarının \%16'sında hastanelerin yeterince organize olamamaları sebepli ikilemde kaldıkları görülmüştür. Yurdakul (2015) yaptığ ç̧alışmasında afetler sırası ve sonrasında sağlık kurum ve kuruluşlarında koordinasyon bozukluklarının olmaması gerektiğini ve hizmet vermeye devam eden hastanelerin can kayıplarını azaltacağını belirtmiştir. ${ }^{24}$

Tablo 3'te UMKE çalışanlarının etik probleminin çözümüne ilişkin yaklaşımlarına yer verilmiştir. UMKE çalışanlarının \%30'u etik problemler ile karşılaştıklarında her zaman yardıma gereksinim hissettiklerini, 1/4'ü etik problemin çözümü için her zaman yardım aldıklarını bildirmiştir. Ayrıca \%20'si etik sorunu çözme konusunda kișisel yeterlilikleri olmadığını düşünmekte ve \%62,7'si meslektaşlarından yardım istemektedir. Hizmet y1lı arttıkça tecrübeyle orantılı olarak çalışanların etik sorun çözme becerileri artmaktadır. Demirsoy ve arkadaşlarının (2018) bir kamu hastanesinde hemşirelerin etik ikilemlere yaklaşımlarını inceledikleri çalışmalarında \%62,2'sinin etik ikilem yaşadığ 1 ve $\% 35,4$ 'ünün etik problemin çözümünde yetersiz kaldıkları, hekim ile işbirliği yaparak problem çözümüne gittikleri bildirilmiştir. $^{25}$

Günümüzde tıp etiğinde pek çok ilkeden söz edilse de, genel olarak yararlılık, zarar vermeme, özerkliğe sayg1 ve adalet ön plandadır. Acil ve afet durumları olağanüstü durumlar olduğu için, bazen sağlık çalışanlarının hizmet sunumunda bazı etik yükümlülüklerini dikkate almadıkları görülmektedir. $\mathrm{Bu}$ çalışmada UMKE çalışanlarının \%23'ü "yararlı olma”, \%20'si "zarar vermeme" ilkelerinin dikkate alınmadığını düşünmektedirler (Tablo 4). Bizim bulgularımıza paralel olarak, Sevimli ve ark. (2015) yaptıkları çalışmasında sağlık çalışanlarının \%25'inin "yararlı olma" ve "zarar vermeme" ilkelerinin dikkate 
alınmadığı görüşünde olduklarını saptamışlardır. ${ }^{8}$ Ayrıca bu çalışmada UMKE çalışanları acil afet hizmeti sunumunda yer alan etik yükümlülüklerden \%19'u özerklik, $\% 17,9$ 'u adalet ve mahremiyet ilkelerinin dikkate alınmadığı görüşündedir. UMKE çalışanlarının tıp etiği ilkelerine daha duyarlı olmaları için etik ilkeler konusunda hizmet içi eğitimlerin artırılması gerekmektedir.

Etik karar verme ve etik duyarlılık bilgi ve deneyim gerektirir. Sağlık çalışanları etik ile ilgili bilgilerinin bir kısmını mesleki eğitimleri sırasında alırken, diğer kısmını da mezuniyet sonrası kurs ve hizmet içi eğitimlerle gerçekleştirirler. $\mathrm{Bu}$ çalışmada UMKE çalışanlarının \%80,2'si etik ile eğitim/kurs aldıklarını belirtmiştir. $\mathrm{Bu}$ çalışmaya paralel olarak Temiz ve ark. (2017) yaptıkları çalışmasında sağlık çalışanlarının \%62'si etik ile ilgili herhangi bir eğitim aldığını belirtmiş ve alınan eğitimle etik sorunu çözme arasında olumlu bir bağlantı olduğunu saptamışlardır. ${ }^{26}$ Han ve ark. (2007) yaptıkları çalışmasında sağlık çalışanlarında almış oldukları etik eğitiminin, etik karar verme süreci üzerinde etkili olduğunu belirlemişlerdir. ${ }^{27}$
Günümüzde sağlık çalışanları meslek değer yargılarını korumada çoğu zamandan daha fazla zorluk çekmekte, hızlı şekilde değişen şartlar güncel ve hak elde edilebilen kararlar verilmesini istemektedir. Sağlık çalışanlarının mesleki değerlerini koruyacak çözüm önerilerini üretebilmeleri için mezuniyet öncesi ve mezuniyet sonrasi dönemlerde etik eğitimi almaları bu anlamda önemli olmaktadır. ${ }^{28}$ Çalışmada UMKE çalıșanlarının \%66'sı daha fazla etik eğitime ihtiyaç duyduklarını belirtirmişlerdir (Tablo 5). Literatürde başka çalışmalarda da sağlık çalışanlarının etik problemi çözmede mezuniyet sonrası etik eğitim ihtiyaçları olduğu bildirilmektedir. ${ }^{27-30}$

Sağlık personellerinin etik bakımdan eğitimi, kurumların etik kurullarının önde gelen görevlerindendir. Eğitimde başlıca gaye, sağlık personellerinin hasta yakınları ve hasta ile olan ilişkilerinde meydana gelen olasi etik problemleri belirleyebilme ve yaşanılan etik ikilemler karşısında doğru karar alabilme duyarlılığının ve anlayışının kazandırılmasıdır. ${ }^{31}$

\section{SONUÇ VE ÖNERILER}

$\mathrm{Bu}$ çalışmanın sonucunda, UMKE çalışanlarının afet durumlarında çoğu zaman karar vermekte zorlandıkları ve etik ikilemde kaldığ1 saptanmıştır. Katılımcıların etik ikilemde kaldıkları konular sırasıyla; afetzedelerin nakilleri sırasında yaşananlar, afetzede yakınlarının çeşitli müdahaleleri, KPR uygulamaya karar verme ve hastane koordinasyonunu sağlamadır. Katılımcıların çoğunun afet sırasında etik çelişkilerinin verimliliklerini etkilediği ve daha fazla etik eğitim alma gereksinimi duydukları saptanmıştır. Ayrıca çalışanların afet hizmeti sunumu sırasında, genel tıp etiği ilkelerinden yararlı olma, zarar vermeme, özerklik, mahremiyet, adalet ilkelerinin yeterince dikkate alınmadığını düşündükleri saptanmıştır.

UMKE çalışanlarına etik problemleri fark etme ve çözme noktasında sık aralıklarla hizmet içi eğitimler verilmelidir. Ayrıca etik ikilem yaşanılan konuların belirlenmesine yönelik ileri araştırmalar yapılması önerilmektedir.

\section{KAYNAKLAR}

1. Kadıŏlu, M., Özdamar, E. (Ed) (2008). Afet Zarar Azaltmanın Temel İlkeleri. Ankara: JICA Türkiye Ofisi.

2. Aydın, İ. (2012). Yönetsel, Mesleki Ve Örgütsel Etik (5 Bask1). Ankara: Pegem.

3. Prieur, M. (2011), European and Mediterranean Major Hazards Agreement (EUROPA), Strasbourg; Council of Europe.
4. Zack, N. (2009) "Ethics for Disaster”, Plymouth, United Kingdom; Rowman \& Littlefield Publishers Inc.

5. Eryılmaz, M., ve Dizer, U. (2007). Afet Tibbı (2. Baskı). Ankara.

6. Eryiğit, U., Saraç, E., Sayar, S., Yetim, Ö., Furuncu, H., Ocak, Z. ve ark. (2011). "NMRT and Trabzon NMRT's Van Erciş Earthquake Operation." The Journal of Acedemic Emergrency Medicine, 11 (1), 55-60. 
7. Orhan, F. (2007). Sağlık Hizmetlerinde Etik Boyut: Hastanelerde Çalışan Personelin Etiksel Sorunlara Yaklaşımlarının Belirlenmesine Yönelik Bir Alan Çalışması (Yüksek Lisans Tezi). Gazi Üniversitesi, Sosyal Bilimler Enstitüsü, Ankara

8. Sevimli, Ș., Dursun, R. ve Karadaș, S. (2015). "Health Professionals of Emergency Service: Evaluation of Triage and Ethical Values in Disaster Medicine." Eurasian $\mathbf{J}$ Emerg Med, 14, 107-12.

9. UMKE. (2016). UMKE Bölge. http://www.umke.org/ (Erişim tarihi 02-07-2016)

10. Tapder, (2017). 112 Sağlık çalışanları ve UMKE, http://tapder.org/ /(Erişim tarihi 07-12-2017)

11. Ünal, Y., Işık, E., Şahin, S. ve Yeşil, S. T. (2017). "Sağlık Afet Çalışanlarının Depremlere Ilişkin Bireysel Hazırlık Düzeylerinin Değerlendirilmesi: Ulusal Medikal Kurtarma Ekipleri (UMKE) Derneği Örneği.” DEÜ Tip Fakültesi Dergisi, 31 (2), 71-80.

12. Başak, T., Uzun, Ş. ve Arslan F. (2010). "Yoğun Bakım Hemşirelerinin Etik Duyarlılıklarının Incelenmesi." Gülhane Askeri Tıp Akademisi Dergisi, 52 (2), 76-81.

13. Pekcan, H. S. (2007). Yalova Ili Cevresinde Görev Yapan Hekimlerin Ve Hemşirelerin Etik Duyarlılıkları (Yüksek Lisans Tezi). Marmaraüniversitesi, Sağlık Bilimleri Enstitüsü, İstanbul.

14. West, T., Ravenscroft, S. and Shrader, C. B. (2004) "Cheating and Moral Judgment in The College Classroom: A Natural Experiment." Journal of Business Ethics, 54 (2), 173-83

15. Özyer, K. ve Azizoğlu, Ö. (2010). "Demografik Değişkenlerin Kişilerin Etik Tutumları Üzerindeki Etkileri.” Ekonomik ve Sosyal Araştırmalar Dergisi, 6(2), 59-84.

16. Gül, Ş., Kuzuca, İ. G. ve Yalım, N. Y. (2016) "Hemșirelerin Etik Eğitiminin Meslek Hayatına Yansıması Konusundaki Görüşleri.” Türkiye Bioetik Dergisi, 3 (2), 85-97.

17. Filizöz, B., Mesci, G., Așcı, A. ve Bağcıvan, E. (2015). "Hemşirelerde Etik Duyarlılık: Sivas İli Merkez Kamu Hastanelerinde Bir Araştırma.” İş Ahlakı Dergisi, 8(1), 47-66.

18. Elçigil, A. ve ark. (2011). "Hemşirelerin Karşılaştıklar Etik İkilemlerin İncelenmesi." Anadolu Hemșirelik ve Sağlık Bilimleri Dergisi, 14 (2), 52-60.

19. Yildı, M. ve Durukan, P. (2004). "Acil Servise Ambulansla Transportu Yapılan Hastaların Analizi.” Türkiye Acil Tıp Dergisi, 4 (4), 144-148.

20. Gezer, D. Ş. (2010). Yoğun Bakım Hemșirelerinin Yaşadıkları Etik Sorunlar Konusunda Adana Ölçeğinde Bir Çalışma, (Yüksek Lisans Tezi). Çukurova Üniversitesi, Sağlık Bilimleri Enstitüsü, Adana.

21. Baștürk, E. (2013). "Do-Not-Resuscitate (DNR) Talimatının Temel Etik İlkeler Açısından Değerlendirilmesi." Türkiye Klinikleri, 11 (1), 12-21.

22. Gönenç, F. İ. (2015). "Hukuki ve Etik Açıdan Resüsitasyon." Sağlık Düşüncesi ve Tıp Kültürü, 36, 5051.

23. Çiçekci, F. ve Atıcı, S. S. (2013). "Mavi Kod Çağrısına Bağlı Kardiyo-Pulmoner Resüsitasyon Uygulamalar Sonuçlarının Değerlendirilmesi." Genel Tıp Dergisi, 23 (3), $70-76$

24. Yurdakul, A. (2015). Kocaeli Derince Eğitim Ve Araștırma Hastanesi, Hastane Afet Ve Acil Yardım Planı. Uluslararası Burdur Deprem Ve Çevre Sempozyumu İcinde (S. 350- 360). Burdur: Mehmet Akif Ersoy Üniversitesi.
25. Demirsoy, N., Türe Yılmaz A. ve Saylıgil Ö (2018). "Hemşirelerin Etik Ikilemlere Yaklaşımları." Journal of Human Sciences, 15 (3), 1568-1583.

26. Temiz, Z. ve ark. (2017). "Cerrahi Birimlerde Calıșan Hemşirelerin Etik Duyarlılıklarının Belirlenmesi.' Anadolu Hemşirelik ve Sağlık Bilimleri Dergisi, 20 (2), 83-89.

27. Han, S. S., Kim, Y. S. and Park, J. H. (2007). “A Study of the Moral Sensitivity of Nurses and Nursing Students In Korea." Korean Journal of Medical Ethics Education 10 (2), 117-124

28. Civaner, M., Sarıkaya, Ö. ve Balcıŏlu, H. (2009). "Uzmanlık Eğitiminde Tip Etiği." Anadolu Kardiyol Dergisi, 9, 132-138.

29. Auvinen, J., Suominen, T., Leino-Kilpi, H., and Helkama, K. (2004). "The Development of Moral Judgment During Nursing Education in Finland." Nurse Educ Today. 24 (7), 538-546.

30. Park, M., Kjervik, D., Crandell, J. and Oermann, M. H. (2012). "The Relationship of Ethics Education to Moral Sensitivity and Moral Reasoning Skills of Nursing Students." Nurs Ethics, 19, 568-80.

31. Aydın, E. ve Ersoy N. (1994). "Hastane Etik Kurullarının İșlevleri.” Akdeniz Üniversitesi Tıp Fakültesi Dergisi, 11 (1), 59-62. 